\title{
Hidden Structure in the Study of Papuanistiecs and Melanesianology
}

\author{
Don Augusthinus Lamaech Flassy \\ Cenderawasih State University, Indonesia \\ donflassys@yahoo.co.id
}

\begin{abstract}
Development until the late 1980s and early 1990s on embodied the initiative of a typical science as the study of Papua titled Papuanistiecs as a course of study at the Department of Southeast Asia and Oceania, Faculty of Arts, University of Leiden-The Netherlands, while Melanesianology lead anthropology has been developed since 1896 when Boas carry out research works in the region of South Pacific and the Southwest Pacific. When Papuanistiecs sounds as a specific branch of the broader Melanesianology include anthropology, the course is not closed for any other specific subject areas, especially on the natural environment as physical nature (tangible) as well as the philosophy as the inner nature (intangible). A concept of intangible or philosophy of Papua-Melanesian on Socio-Cultural structure is what being proposed in this writing work as a "hidden-structure" or 'covered structures'. The term or this formula was by the author uses to accommodate referrals various scholars who call the social structure of Papua-Melanesian as "loosely structure" or a missing structure and also as "confusing diversity" or as confuse or chaos diverse. That, "hidden structure" is said to be so because it is hidden to those outside the system which understanding as ethics while looking for people in the system who view of understanding the relationship of emics accused loose or off and confuse or confusing is very well lightly acknowledge. Melanesianology and Papuanistiecs very well coordinated by the Sydney University and the Australian National University in Canberra by enabling the University of Papua New Guinea/UPNG in Port Moresby PNG and the University of the South Pacific/USP, in Suva-Fiji. In addition to its general purpose by making Papuanistiecs and Melanesianology as a discipline of area regional study, the special purpose of the author also is about to raise these matters in connection with the State University of Cenderawasih who have declared itself as Anthropological Study Base, then the function of Papuanistiec and Melanesianology may be of the major studies take precedence in all disciplines.
\end{abstract}

Keywords: Papua-Melanesia, the hallmark mosaic of all non-uniformities

\section{Introduction}

Making of thought process in this case is a distinguishing feature of man kind as homosapiens or thinking beings with other creatures. Thus thinking is a process that led to knowledge. This process is a series of thought in motion following the path of a specific meaning which finally came to a conclusion in the form of knowledge. Human thinking to find comprehension or understanding, forming opinions, and conclusions or decisions of something desired. Studies with an alternative approach from the viewpoint of Ontology, Epistemology and Axiology are in Philosophy of Science and Scientific Thinking. With the scientific basis of the theory of the topic Making of "Hidden Structure" [1] in the Social-Cultural of Papua Melanesia approached as a framework regard the Studies of Papuanistiec and Melanesianology. Melanesianology and Papuanistiec are very well coordinated by Sydney University and the Australian National University in Canberra by moving the University of Papua New Guinea/UPNG in Port Moresby PNG and University of South Pacific/USP in SuvaFiji. If the Cendrawasih University has nuanced itself Based Science on Anthropology, then the function of Melanesianology and Papuanistiec can become major studies take precedence in all disciplines as the inevitability of meaning.In this regard to philosophy as a science in this meaning of its trademark shades that is speculation, doubt, curiosity and interest to reveal the essence referred to here as "hidden-structures". This is because philosophy can also mean a trip to the deepest thing that is usually not touched by other

\footnotetext{
1The term "Hidden Structure" the author first appear with in the article entitled Toror, a name beyond the Language and Culture Fusion, PhD Dissertation draft, Leiden, State University-The Netherlands 1991 in the meaning of the SocialCultural of Papua-Melanesia as a basic theory of specific and unique. So on the basis that the author have come up in various writings over the years; therefore, there may be aspects that are not covered or are there gaps that need to be improved and supplemented.
} 
disciplines, namely with skepticism to question everything, in this specific "Hidden Structure" within the meaning of the Social-Cultural of Papua Melanesia.

\section{Theoritical Review}

To understand the details of academic and scientific Hidden Structure of the Socio-Cultural meanings of Papua Melanesia as Study of Papuanistiec and Melanesianology let desired in this study is given basic and theoretical summary of each feature linkages as follows:

A. FoS: Guided by School of Leiden Anthropology, the Structuralism Anthropology to the concept of regionalism called FoS (Field of Anthropological Studies) until now very many scientists, researchers and scholars have claimed archipelagoes of Oceania consists of Melanesia, Polynesia and Micronesia as a regional and global subject areas namely an ethnographic study region: Taal-Land-en-Volkenkunde (linguistic, cultural, and tribal studies).

\section{Fig. 1: Oceania (Melanesia, Micronesia and Polynesia) flanked by Australia and Insulander}

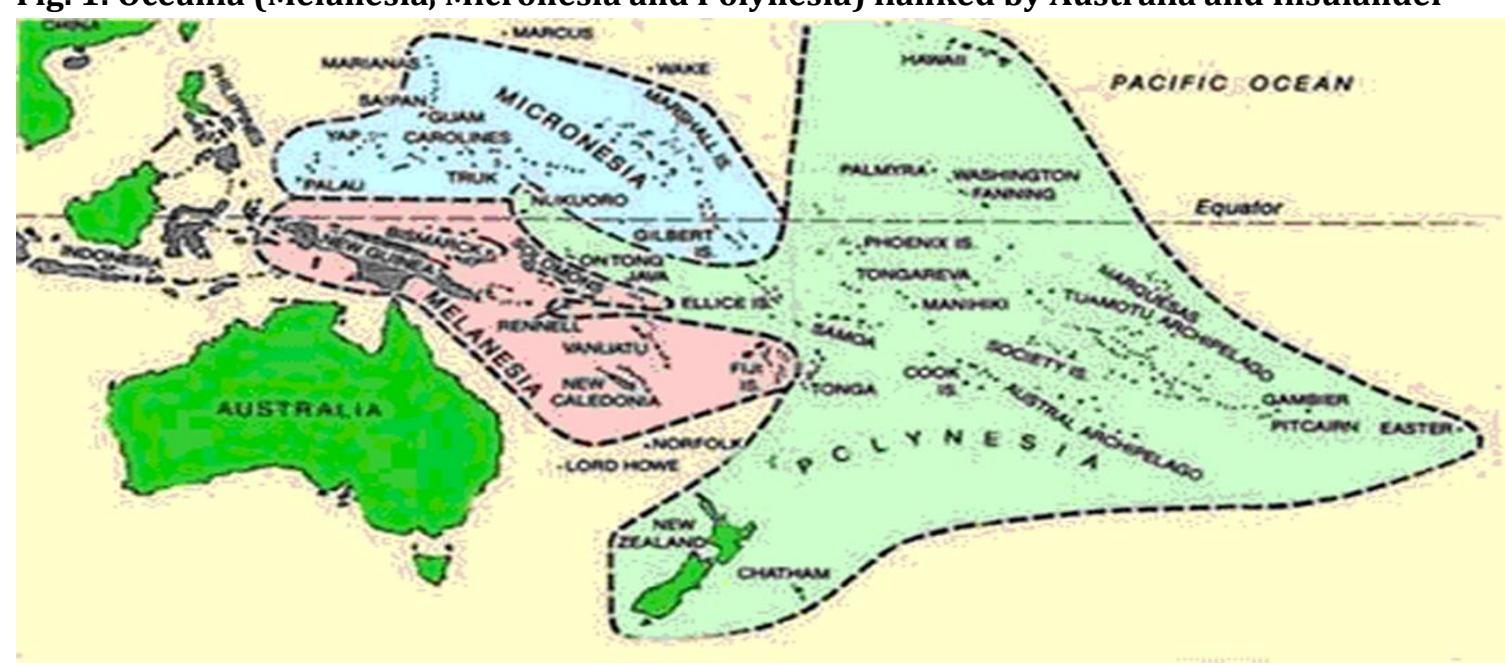

Proof has been given specific basic discipline as well Indologie studying Indonesia, Chineologie about China, Arabiren of Arab, also Africa, Caribbean, Latin. America, Slavish and so on. The presence of clumps MalayoPolynesian (Austronesian), then there is the distribution of target areas of FoS to Oceania and Southeast . Asia into a single Department found place in Faculteit der Letteren, Rijks Universiteit te Leiden called Vakgroep Zuid-Oost Azië en Oceanie (Department of South- East Asia and Oceania). Then here and here PapuaMelanesian specific in defining "hidden structure" or "covered structure".

B. Structure: The said structure is the fundamental idea, tangible or intangible refers to the recognition, observation, nature, and immortality patterns and also relationships of entities. This idea may itself be an object, such as the structure is built, or attributes, such as the structure of society. From verbal description e.g. placemat snowflakes, for scientific analysis of the detailed properties of the magnetic field, the concept of the structure of the present is often an important foundation of nearly every mode of inquiry and discovery in scientific knowledge, philosophy, and art (Pullan, 2000, Structure, Cambridge: University Press.), In the 20th century's and forethought, the form often plays a role comparable to the structure of contemporary thinking. Cassirer (cf. Philosophy on Symbolic Form, completed in 1929 and published in English translation in the 1950s) is sometimes considered a precursor of the shift then structuralism and post-structuralism (Rowe, 1995). Description of implicit structure offers an explanation of what the system is made of: a configuration item, a collection of interrelated components or services. One structure can enable a hierarchy (a cascade of one-to-many relationship), network-featuring many to many links, or grilles which shows the relationship between the components e.g. solar system in space. 
C. Social Structure: Social structure is the relationship patterns of social organization of individuals in various life situations. Structure applies to people in the way society as a system organized by a characteristic pattern of relationships. This is known as the social organization of the group. Sociologists have studied changes in the structure of these groups. Structures and institutions are faced with two theories of human behavior. The debate about the influence of structure and agency on human thought is one of the central issues in sociology. In this context, the institution refers to the human ability of individuals to act independently and make a free choice. Structure here refers to factors such as social class, religion, gender, ethnicity, customs, etc. which seem to limit or affect the chances of an individual (Scott, 2012).

D. Hidden Structure: About hidden structure mentioned here may or may not be equated with the shape of the Sweden hologram on the light sun that appeared in this country in every 3rd of April [http://holocenter. org/what-is-holography/?gclid=CMPZs8fg7McCFRYW jgod4hcPIw] and also of shimita namely Jewish abundance Sabbath of Sept. 13, 2015, 2008, 2001, 1994 with intervals every seven years is also affecting the world economy slumped, especially of the United States [This cycle effect on the world economy, especially that of the US (www.lazerbrody.typad.com)]. Besides the idea of complexity states that matters most tend to organize themselves into repeating patterns, even when these patterns are not immediately visible by external observer. The common name for the scientific fields concerned with the behavior over time of dynamic systems 'theory of complexity' says: system is dynamic, the system is able to change from time to time - is the focus of this approach, and attention is the predictability of the behavior of the system attractive for complexity theory, under certain conditions, appear regularly, such as how to predict; in other conditions showed regular behavior but also lost predictability. The concept is of the behavior of the stable and unstable part of the repertoire of traditional physics. What is meant is the concept of a chaotic behavior. For the chaos here is seen as a system that presenting behavior, although it has a certain regularity however, against predictions order emerging from chaos. And indeed how could, predictable behavior of a chaotic system. Nevertheless, the complexity of the idea that every, everything is most likely to organize themselves into repeating patterns, even when these patterns are not immediately visible by external observer. But really, what to be reason of the author (1992) uses the term "hidden-structure" is with a view refuted the opinion of experts on culture for example Alex v / d Leeden on mating systems of the inland communities of Sarmi said loose (apart) or loosely structured (not organized) as well as in Africa. Or also the word used is confusing diversity. That is there for, will the author to states that the existing structures for people outside the system (ethics) is indeed seem so, but for the people in the system (emic) the relationship between the structures are clearly visible.

E. Structure Linkage: According to Wikipedia, in the science of natural herbs, the future advances in plant genomics will allow it to scan the genome for polymorphisms associated with the properties of both qualitative and quantitative. Before this potential can be realized, we must understand the nature of the linkage disequilibrium/LD (non- equilibrium linkages in the genome. LD, nonrandom association of alleles at different loci, plays an integral role in the association mapping and association studies determine resolution. Recently, the association mapping has been used to dissect quantitative trait loci/QTL. With the exception of maize and Arabidopsis, little research has been done on LD in plants. Species mating system (selfing vs. cross), and phenomena such as population structure and recombination hot spots, can greatly affect the pattern of LD backs. The basic pattern of LD in plants will be better understood as a species analyzed. In this respect the social sciences are led to deep structure (inner structure) to the surface and also by the historical relationship.

F. Structuralism: In that regard structuralism (structuralist flow) in cultural anthropology is a school of thought (thought of learning) developed by the French anthropologist Claude Levi-Strauss, that the culture, viewed as a system, which analised in terms of structural relationships between elements. According to the theory of Levi- Strauss, universal pattern in the culture system is the product of the invariant structure of the human mind. For Levi-Strauss, the structure mentioned exclusively covering mental structure, although he found evidence in the analysis of such structures far-covering kinship, patterns in mythology, art, religion, ritual, and culinary traditions (food system). The basic framework of Levi-Strauss's theory comes from the work of structuralist linguistics NS Trubetzkoy, underlying the study of 100 of the 361 words (vocabs). Furthermore Leiden structuralism is based on the understanding that the Sausserean (Ferdinand de Saussure) of la langue (the element or inner structure) and la parale (element of surface or conversation). 
Structural Anthropology which is based on the idea of Claude Lévi-Strauss is 'the idea of people thinking about the world is in terms of binary opposites (opposition) - such as high and low, inside and outside, people and animals, life and death - and that each culture can be understood in the case of such inconsistency. "From the beginning," he wrote, "the process of visual perception that use binary opposition." Structuralism and Ecology (1972), approach of Levi-Strauss' appears, in essence, of Hegel's philosophy which explains that in every situation there can be found two opposites and resolution available to him, he called: "thesis, antithesis, and synthesis". Levi-Strauss argued that, in fact, culture has this structure. He shows, for example, how the conflict of ideas will collide and will also be resolved in the rules of marriage, in mythology and ritual. This approach, according to him, made for new and fresh ideas. He stated: "Only those who practice structural analysis resuscitated by their daily work what they are really trying to do: namely, to reunite the perspective of the scientific view that is narrower than the last century has been too long believed to be mutually exclusive: the sensitivity and intelligence, quality and quantity, real and geometric, or as we say these days, "ethics" and "emic." (Pike, 1967; 1972).

\section{Discussion}

Development until the late 1980s and early 1990s realized an initiative of the sciences of the typical study of Papua as Papuanistiec $\left[{ }^{2}\right]$ as a course of study at the Department of Southeast Asia and Oceania intended (Stokhof, 1988, IRIS-ISIR Project) while the Melanesianology leads anthropology had been developed by Boas since 1896 carrying out research work in this area[[3] (South Pacific and Southwestern Pacific). Melanesianology and Papuanistiec very well coordinated by Sydney University and the Australian National University in Canberra by moving the University of Papua New Guinea/UPNG in Port Moresby PNG and University of South Pacific/USP in Suva-Fiji. Throughout the other adrift, has been pegged to Tanah Papua[ $\left.{ }^{4}\right]$ covers the island and surrounding islands are among others by Wurm (1982) referred to as the land of 1000 languages or where spreading of 13 to $15 \%$ of the number of languages in the world which is approximately 260s languages or more in West Papua (Indonesian Territory of Tanah Papua) and approximately 750s languages in the Sovereign State of Papua New Guinea. Besides pegged in 3 bio-geographic boundaries so that a specific characteristics. [5]

\section{Fig.2: The nature of Bio-Geographic separating Tanah Papua, Aru, Australia and Tasmania from west direction of Wallacealine, Weberline and Lijdekkerline.}

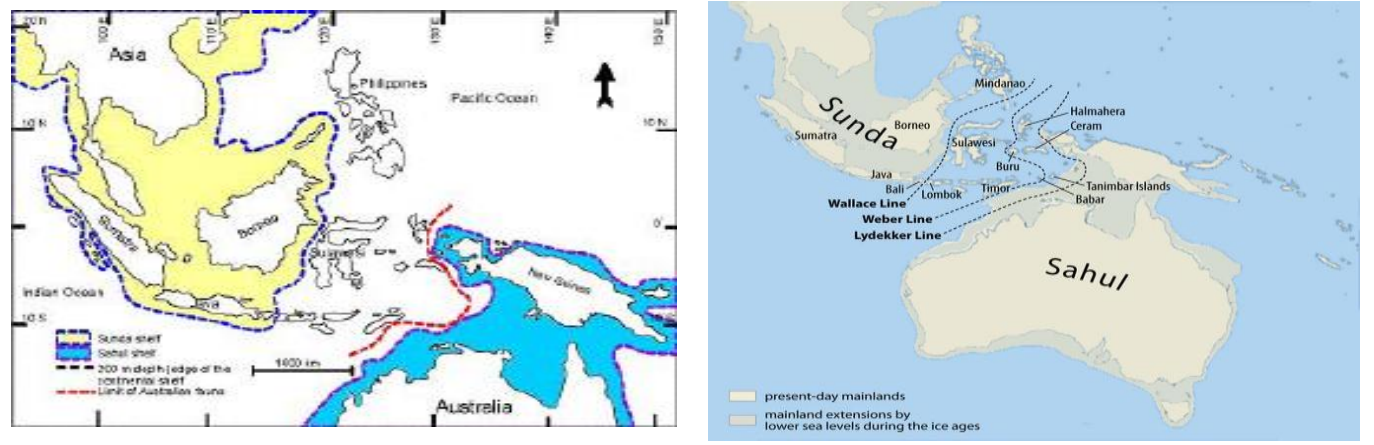

2 Flassy in Mansoben, et.al, Proceedings of International Conference on Papuan Culture Diversity in The Mosaic of Indonesian Culture, Jayapura, 2010: 21-79.

${ }^{3}$ Also do Borislav Malinowsky and Margareth Mead in decade of 1950s and then keep developed in the Pacific mainly by Sydney University and Autralian National University (ANU) Canberra.

4 The existence of RI Law No. 21 of 2001 on Special Autonomy for the Province of Papua is so that the issue here is not the reality of the division of the provinces. While the Natural Bio-Geographical of Papua (New Guinea), Aru, Australia and Tasmania in the limit three natural barriers marked as Wallace Line, Weber Line and Lijdekker Line. Papua is thus not a single and easy drawn to digest but is a very diverse and very complex.

5 In this regards, the author appreciates the Melanesian and Papua writers among others Ben Narakobi for his work 1980 Melanesian Way and J.R Mansoben for 1994 Sistem politik tradisional di Irian Jaya, Indonesia (Traditional political system in Irian Jaya, Indonesia) is Melanesian Papuans who writes about themselves and also Bernada Meterai who appeared in 2012 with Nasionalisme Ganda Orang Papua (Dualistic Nationalism of the Papuans). 
Languages that exist, classified into two major groups, based on the characteristics of each language group. As for the group or family of languages in question is a group of Austronesian language family traits and characteristics of a group or family of languages of Non-Austronesian language family or trait Papua. To West New Guinea, some examples of languages which are characterized as Autronesian languages are Wondama, Waropen, Numfor-Biak, Namatota, Onin, Mor, Ansus, Ambai, Liki, Ormu, Kayopulo and Tabati which is a distant relative of languages with the language groups of Melayu, Batak, Jawa, Gorontalo, Kei-Evav, and a variety of other languages. Meanwhile for those characterized as languages of Non-Austronesian or Papuan languages further classified into several groups for this purpose only mentioned three areas or phyla (phylum) [6] which are Phylum of Geelvinkbay, Phylum of Trans New Guinea and Phylum of West Papuan. If the Phylum of Geelvinkbay only covers about Gulf of Cenderawasih mainly languages of Yawa inland of Island Yapen and Tarunggare along the coast between Waropen and Nabire, where the Phylum of West Papuan covering languages in the inland, west and northern Bird;s Head of Tanah Papua and of North Halmahera North Maluku, further the Phylum of Trans New Guinea covering nearly the whole Tanah Papua also including South of Bird;s Head and also of the island of NTT specifically Pantar, Alor and Timor.

Of the two linguistic patterns that are marked as Trans New Guinea Language Phylum that is actually a feature of the center while West Papua Language Phylum and the other is more of peripheral as an intermediary with the elements of Austronesian Languages. This fact, among others, strengthens the mosaic of Papua- Melanesian designation as part of the Melanesian culture. Cultural traits, among others even though there is an element of Austronesian but still distinguished with that of Malayo-Austronesian and IndoMelanesian (Maluku, NTT, NTB, Moro) which in order of kinship adheres to the pattern of bilateral patriarchal-matriarchal distinguished by Papua-Melanesia which has kinship order of unilateral patriarchal.[7]

\section{Fig.3: Map of Language Phylum in West Papua and surounding islands west}

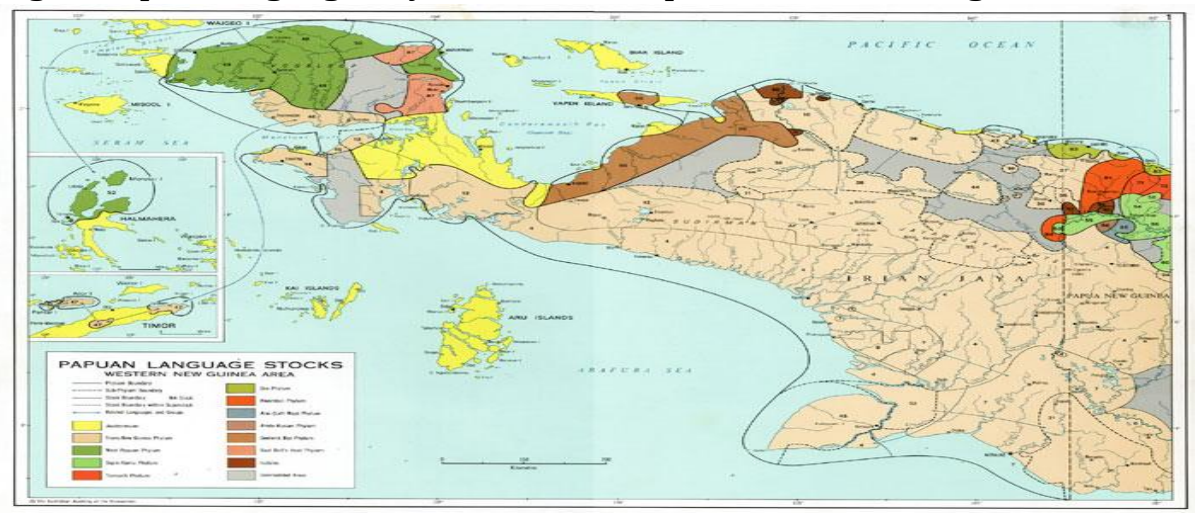

About the kinship patterns in Tanah Papua, Mansoben (2009) by pointing Pouwer (1966) stating, there are 4 types of kinship classifying, which are: (1) Iroquois Type, with characteristic groupings, members of relatives cousin parallel using the same term with siblings, is different from the term used for a cousin of the cross that is marked on the Biak, Waropen, Gulf of Humbold (Numbay) which is of the Austronesian language

\footnotetext{
6 If the Austronesian and non-Austronesian was obvious is the difference in vocabulary as well as various aspects of grammatical, while Phyla or Phylum determined based on the kinship between languages characterized by the similarity of vocabulary, sentence structure and futures of language such as flexion, gender differences of 3rd person (he and she), difference due to the influence of verb in grammar of singular and plural-and tenses. Take wording SPO on Austonesian language "(S) I (P) eat (O) taro" will be the same as in Tehit language which is a Papuan language of West Papua Phylum also known to the characteristics worthy of SPO "(S) Tet (P) tat (O) qam" will be changed the order of the language which is the language Bahaam of family Phylum Trans New Guinea, became, SOP "(S) Andu (0) kadi (P) nowa". Another difference with Austonesia is in Tehit word "at" eating on the plural would be "eit" while in Bahaam "nowa" in the adjustment of tenses will be "nowa nde - nowayet - nawi yende" (not enough space to explain here), see Flassy et al, 1984, Struktur Bahasa Bahaam (Language Structure of Bahaam).

7 Trench of kinship in Papua is in the lineage of the father (patriarchate) is different from the people who embrace Minangkabow uncle or mother's lineage (matriarchate) and the rest of the entire Malay/Indonesian practice of both sides of the trough kinship (patriarchate-matriarchate or bipartite).
} 
characteristics, but also on the Iha, Senggi, Marind-Anim, and Me, which is of languages of Trans New Guinea Phylum; (2) Hawaiian Type, with characteristic groupings, members of relatives use the same term to refer siblings and all the cousins cross and parallel, at the Mairasi which is the language user of Bomberai Stock Isolate, the Hattam-Manikion which is the user language of Papua Stock Isolate Bird's Head, the Mimika, the Asmat, the Kimam, who are the language users of the Trans New Guinea Phylum and the East Coast Sarmi the user of Austronesian languages;(3) Type of Omaha, with the characteristics of a system that clarifies cousins cross matrilateral and patrilateral with different terms then terms for cross cousins was influenced by the levels of generation and are not symmetrical, so the term for son of mothers brother (mother's brother's son/MBS) is same as the brother of the mother (mother's brother/MB) and the term for the son of father's sister (father's sister's son/FZS), is the same for son of the sister (sister's son/ZS), recorded on the people of Meybrat who is the user of Papuan language of West Papuan Phylum and the Auwyu, Dani, Mek and Muyu who are languages user of Trans New Guinea Phylum languages; (4) Type of Hawaiian-Iroquois, recorded in the Bintuni, the Tor as the user of Papua language of Trans New Guinea Phylum, but also the West Coast of Sarmi who are the users of Austronesian languages.

Nonetheless a child is the father's and of course can not be separated from responsibilities of its uncle and the parallel family. In the sense of entrainment is also in the system of descent inheritance. $\left[{ }^{[}\right]$Accordingly, except for the classification of the population of Papua by the system referred to kinship terms, this view is corroborated also by the principles of inheritance of descent that adhere to the principle of descent inheritance through the paternal or patriarchal. In shades of this discussion, both kinship relations, idealism, or else action and the production does not appear transparent so hard to follow then of course there is the terms of confusing diversity, asymmetry (not symetrics), savage or vulgar (wild), and also loosely structured (or unstructured) which is in this written work refers to as hidden structure (covered structure). Accordingly, the mentioned here, understanding of "hidden structure" in this exposure, is a continuation of the familiar Field of Study (FoS) were interpreted in Structural Anthropology Leiden, by which A. v/d Leeden, 1956, in his thesis at the Rijksuniversiteit te Leiden with the title: Hoofdtrekken der sosiale struktuur in Binnenland van het westelijke Sarmi (Drawing head of the social structure in the western interior of Sarmi) claimed, culture in Papua-Melanesia, especially concerning marriage patterns (marriage alliances) as a "loosely structured". The opinion had invited debate the pros and cons it is a direct comparison with the cultural patterns (marriage) in Africa are so clearly structured. View or understanding is challenged by various colleagues in the Bureau of Nieuw Guinea Studien (NGS), especially in this case J. Power, 1959 in the title Loosely Structured Societies in Netherlands New Guinea, Hollandia, NG Studien (See also Barnes, 1948 African models in the New Guinea Highlands', in Man 2: 5-9). Many things in people's lives can serve as an example of the existence of hidden structure in this case to the attention of the author and try to explain how social structures that do exist even though no visible or covered (hidden and latent).

This understanding will be explored by the method of connecting structure (structure linkage) to find and will build up to the surface in terms of links between the visible and the under secrete alias invisible or have been and still escape at the sight and the understanding of outsiders (researchers, scholars and scientists) and may even be completely hidden for the layman and common understanding and implementing government policy. This fact shows that the concept of the person or the so- called emic view is mostly hidden or escaped from the view of outsiders because most just underlies the view outside or called an ethics mere (Pike, 1967). Many examples of how the hidden structure of relationships within a culture, for example, the culture of the majority residents of the Bird's Head with the power of sacred cloth or eastern cloth which is a medium of exchange and a means to pay with the concept of a party, initiation, war, death, barter, marriage and another various aspects. [ $\left.{ }^{9}\right]$ In other cases the Amungme refer to the earth as mother[10], then, for

\footnotetext{
8 The real story: Dr. Musa'ad an Arab descent but of biological mother was Siblings of King Fatagar (from FakfakBomberai Culture Area) his candidanct proposal for deputy governor was rejected by Majelis Rakyat Papua (Papua House of Representative)/MRP because although the biological mother is Papuan women but he is not a descendant of Papua as he is the son of the father who is an Arabic.

9 Elmberg, 1966, The Popot Feast Cycle in Ethos, Stockholm: Statens Ethnografiska. Musset; 1968, Balance and Circulation: Tradition and Change Among the Meybrat of Irian Barat, Stokholm-Etnografisika Musset Monograph Series No.12.
} 
example, will constitute an environmental dimension which can therefore be expressed by connecting the structure to reveal "hidden structure" is real to the surface. Similarly, in the group of Marind Anim which each finished splitting oka 'coconut' and mess 'desiccated coconut' all the rest of the skin or shell and wastes buried or covered with sand or soil.[11] The outsiders who see this behavior so impressed that how these simple people understated preserve the environment so that the garbage and even bits of coconut only have buried neatly, but in fact is not so, because coconut is a family's totem should trimmed in order to avoid clashes with the owners of the totems as well as with the realm spirit (dema) supporting totem meant. Universally, indeed, may be "hidden structure" or "hidden structure" exists, though appeared diverse. To that end, in uncovering the structure of these hidden there must be a lot of methods is needed, as has been mentioned before, oneof them is the method of connecting structures (structural linkage) to know and understand and support the understanding "hidden structure" as a theory.

Entering the nuance of "hidden structure" many dots are exceeded among other emotional ties, sympathy and antipathy even any variety of processing methods of conflicts. As the "hidden structure" has indeed been marked and clear to researchers, is to support the theories that have been developed by various researchers, among others by Feil (1979) is about the close relationship between pigs and sweet potato (Ipomeas batatas) are reciprocity with polygamy in the mating system in the Central Highland PNG. In a sense against the background of the school of British, Functional Anthropology (British Strand of Functionalism Anthropology) that emphasizes on productivity, indicated by Feil, can be interpreted functions which are highlighted so that it appears to the surface what is hidden, or meant by "structure hidden ". In addition, there are also other people with different topics can be demonstrated or explained so that no impression of "loose structure" or even "hidden structure". Gerbrand (1970), for example, will bring up an interesting concept with the title "Taal der Dingen" (Languages of things) or language objects emphasis on cultural material (material culture), especially in the art, it has been predicted offs with the main points of Anthropology structuralism Leiden as told above about FoS to "loosely-structure" in the socio-cultural relationship of Papua-Melanesia.

Aware of "hidden structure" helps mutual understanding between people outside the system and the people in the system in an attempt of adhesives to counteract the tendency of cohesivisme growing increasingly strained time tends to nullify the deal and the followings on. On understanding the purpose of the above and with underlying 7 to 9 system of universal ethnography that there are 7 to 9 system ethnography which is a system of environment, livelihood, kinship, political (power and alliances), confidence (initiation and worship), technology, language , arts and utilization of spare time as well as physical build of the human body and makeup, (Koentaraningrat in Pengantar Antropologi (Introduction to Anthropology) 1986), has been useful leads this author since 1983 through 2013 (produce books Aspek dan Prospek Seni Budaya Irian Jaya (Aspects and Prospects of Arts Irian Jaya), 1983, Jayapura, local government of Irian Jaya, and then Aspek dan Prospek Seni Budaya Papua (Aspects and Prospects of Cultural Art of Papua), 2013, Jakarta, Balai Pustaka) basing on the Dutch scholar's working of Held (1951) and Gerbrands (1975) peged the Territory of Papua and Melanesian culture as following map:

Reality of diversification has encouraged the author (1983) initiated the classification of the Culture Regionalism in Tanah Papua into 5 areas of culture then beyond the Papuan Customary Council Conference 2001 was held to 7 Cultural Autonomy Regional's which are 5 majors and 2 developed, respectively: (1)Tabi,

10 Personal consultation with Tom Beanal, a chief figure of Amungme tribe, 1999 in Jakarta. Accordingly, Muffet an Americans owners of Gold Mine Freeport has been accused of desecrating the initial meeting described with words winged (pleonasms and euphemism) as: "You have been received in the "noken" (emblem of feminine, vagina, thighs or lap of mama) but you have besmirch the treatment of an indecent nature and we abandoned the wealth of our earth, our mama ..... and so on." Data was also obtained empirically in meeting the initial launch for negotiations of $1 \%$ and $2 \%$ Profit Sharing from Freeport Mine returned to the people of 7 tribes, in Timika, 1997. The author was present in the capacity of Secretary of Irian Jaya Planning Board also together with Mr. Michael Menufandu accompanying the Governor Fredy Numberi.

11 In addition to empirical experience in Merauke when study at SPG of 3 years period, can also be obtained knowledge of Baal, 1966, DEMA Description and Analysis of Marind Anim Culture (South New Guinea), with the collaboration of Father J. Verschuren, MSC, The Hague, Nartinus Nijhof, special on three religious streams in Marind rate: Azam, Zozom, and Mayo. 
(2) Saireri, (3) Bomberai, (4) Do(m)berai, (5)Ha-Anim, (6) Lani Paqo and (7) Me Paqo. Further studies led to the development of deep insights then there are 14 characteristics of the cultural regionalism of Melanesia. In this case in Papua New Guinea there are 5 (number 8 to 12, see Fig.: 1) included the Torres Strait Islands Group. Because it is so complex it would require the equivalent of term that encompasses so it is not just a cultural region. Thus the linguistic and likely botanic term of "stocks" been obtained so then the term superstock then used for Culture of the Melanesian Cluster Islands of the Southwestern Pacific (Fiji, Vanuatu, New Caledonia, Solomon Islands and Bougainville) is numbered 13 while from the power of regionalism the term or word empire is obtained to Melanesia in Insulander of Indian Ocean numbered 14 (Maluku, Nusa Tenggara, and Moro), still needs to be explored further.

\section{Fig. 4: Culture Area in Papua and Melanesia}

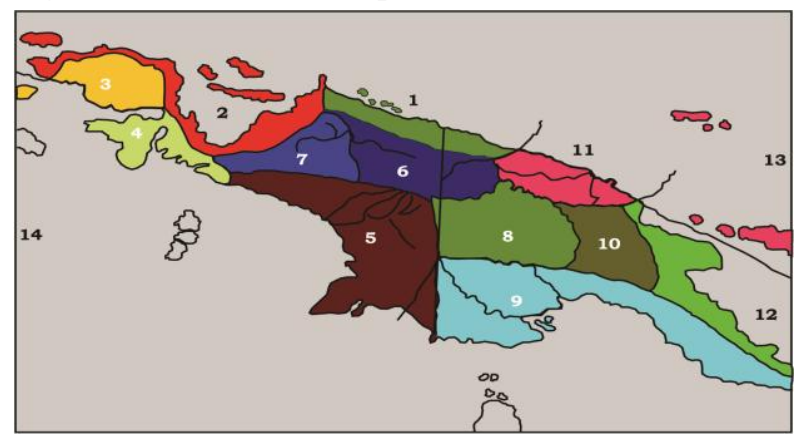

Again Culture Area in Papua and Melanesia agian skatered as: 1) Tabi also mention as Mamta (MamberamoTami) around Jayapura-Capital of Province of Papua, 2) Saireri (Cenderawasih Bay which exspanced eastward to the Wogow archipel in the Pacific and to westward to Raja Ampat archipelago and some setlements in Northern Maluku. 3) Doberai (Bird;s Head: Manokwari-Sorong-Bintuni). 4) Bomberai (FakfakKaimana). 5) Ha-Anim-(Mimika-Merauke). 6) Lani-Paqo (Eastern Highland). 7) Me-Paqo (Western Highland). Where in PNG : 8) Sepik. 9) Huon. 10) Orokolo. 11) Enga. 12) Chimbu. In the Southwest of the Pasicic Ocean: 13) Superstock Culture Regionalism of Melanesian Island in the Pacific (Fiji, Kanaki, Vanuatu, Solomon, Kiribat). In Southeast Asia: 14) Empire of Melanesian archipelago (Maluku, Nusa Tenggara and Moro of Southern Philippines). This meant that the knowledge of regional studies recognized as the essence of which should be realized. So with the development of society in any form should be done by culture approach (cultural approach), especially in this case the characteristics of zoning in Papua and Melanesia in general.

Culture and Philosophy of Melanesia: Is there what is meant by the Melanesian philosophy? Before answering the question, of course, there are other things that need to be straightened out in this connection that "Is there what is meant the Melanesian identity? There is opinion and assumption that the classification of the Melanesian race is to be inaccurate $\left.{ }^{12}\right]$ because it ignores the larger culture, language, social, and genetic diversity in the region. Not to mention if it covers countries, especially in the context of this case in the west mostly easternmost region which are not Malay or Indonesian. Then of course there are many parties argue that there is no single way of life or a "Culture of Melanesia", but the philosophers of Papua New Guinea, Bernard Narokobi denied this debate, with fundamentally emphasized that Melanesia indeed is a unit of culture and or way of life, in his written work entitled The Melanesian Way.[13] That is meant Melanesia is a concept, a compound word, a genera that is based on the description (of experts of various disciplines) as expressed above, Melanesia Beyond Diversity is exists.

Melanesia as universals: Melanesian culture and way of living is envisioned as a place or a public forum for the contemplation of the world and domestic events and opinionated of people of Melanesian people. Melanesian people manage and maintain life in the islands of their existence was already thousands of years

12 Nicholas Thomas, Allen Abramson, Ivan Brady, RC Green, Marshall Sahlins, Rebecca A. Stephenson, Friedrich Valjavec dan Ralph Gardner White, The Force of Ethnology: Origin and Meaning of Melanesia/Polynesia, in Anthropology Event, Vol. 30, No. 1 (Feb., 1989), pp. 30, No 1 (Feb, 1989), pp. 27-41.

13 Bernard Narakobi, The Melanesia Way, 1980, Institute of Papua Nugini Studies, pp.199, Narakobi, The Melanesian Way, 1984, p. 185. 6. 
before Europeans came and relate to them. It is assumed for the people of Melanesia have had already civilization with their culture, the value of life, knowledge and wisdom that has guided them through the ages. Through all of the truth they believe in is revealed, accepted and enshrined in the way of life and the concept of thinking become the focal points of civilization. Civilization has lasted long time and gives greatness, freedom and space, and self-esteem in the history. Melanesians became themselves because they accept themselves as who and what they are without denying or avoiding the autonomous of self and their existence. Admittedly, the history of Melanesia is not in the world of writing documents. Melanesian civilization does not have the wheels to the distance traveled and did not have the power of ammunition tong, cannons and rifles as well as guile hegemony. But these things exist and we have because the linkage between nations, especially in this case with the European world, is no less important as we have a culture pottery of Donsong in Sentani, culture of Chinese Porcelain in the Gulf Saireri or culture of Eastern cloth in Doberai and of course Ceramics of Lapita culture in the areas of Oceanic Super stock culture (Southwest), see this description before on Culture Area which in the beginning based on 7 or 9 aspects of the culture or the specific conditions which of course implies the values of philosophy.

Because of our unique circumstances, then, we are very limited for influencing the world of civilization. In a sense, it is still an immortal human experience. But now we are blessed with the talent to write words and privilege rolling. We can reflect past Melanesia rushed through our modern life. We may have a responsibility to ourselves and the world by bringing the personality and property of our civilization. It is already so far we can only find out about ourselves through the books written by others. [14] From the intersection that we may have the opportunity to build universals that can be spoken in the language of Malay/Indonesian, English, French dyed in so-called Melayu-Papua, New Melanesian (Melanesian-English, Pidgin or Tok Pizin[15]) as well as in French, Dutch, Portuguese and even in Latin and Greek or Hebrew and also formulas of other communications given the diversity of languages that we have inherited is not able to break through the universality due to the limitations but also the robustness of our autonomy. Will it be viewed and understood from creation, every person in the human community, whether called a village, clan, tribe or nation, inherited the image and sense of good and bad according to its sources that is contain specific meaning but is becoming nomenclature. Therefore, good or evil can not be cheers in Melanesia, in the kinds of unique tribute to ourselves; while on the other side we share with other communities through the intersection of the world. It is not intended for logic of a syllogism or immortality meant to be used as input to think in human life and in the form of experience that contains inconsistency, contradiction, emotion, reason and intellectuality. A wide range of publications begin contemplation of the case of this main subject, including matters of religion, spirituality, culture, law, education, politics, economics, administration, library, business, history, sports and technology, and more in charge of a long list of contemporary (especially in the part of Melanesia which has become an independent and sovereign state).

Melanesia as Essence: The existence of Melanesia envisioned freely as a positive, creative and constructive force. This targeting in good sense, beautiful and honest as a consequence of the existence. Melanesia is a news or oriental principle rather than bringing people directionally specific opportunity would be misleading. In this regard would not think of human weakness, except in the case referred to advance the understanding of truth or positive, healthy life as well as a healthy, comfortable and prosperous desirable. Hopefully, through that understanding, Melanesia has a view that is also essential Melanesia which allows seeing the world as it should be there. Melanesia consisting of West Papua, Papua New Guinea and the islands around it which are the Solomon Islands, Vanuatu (Ex-New Hebrides), New Caledonia (Kanaki), and Fiji as well as the Torres Strait (between Papua and Australia) but also to the west, namely on East Timor, Nusa Tenggara (East, West) and Maluku even too Moro in southern of the Philippines. Melanesia is indeed a unique style of human performing, not a clump of Asia and Europe, in addition to at the same time nor Africa, the Caucasus and Polynesia (and Micronesia). Not associated with light skin because even though here and there, there is also

\footnotetext{
14 Besides the mentioned pioneer Bernard Narakobi and a series of names in PNG, priced well worth to Johsz R. Mansoben (1994) who mapped the 4 shades of traditional leadership in West Papua and certainly also reflected in Papua New Guinea and Melanesian islands.

15 The name for this Pidgin is varying by nation and the Melanesian countries, for example in Vanuatu called Baslama. As for the official texts such as text of political manifestos, declarations and laws were written in standard Malay/Indonesian, English or French including textbooks for science, common and popular.
} 
no Melanesian people with light skin color (not albino) were very common. Melanesia has been invaded by a large wave of immigration from the west in various form of material culture, philosophy of life, religion and the latter in particular shades of Christianity along with colonialism. Like most western civilization coming wave lashed mercilessly, with all the power and prowess, on top of our existence in the real world we are not infrequently we are not aware of our own existence. The new wave of civilization that have destroyed our property, take piece of land rich in minerals, in addition to not doubt, because, also left a lot of garbage pollution physical, mental and spiritual.

Some Assertions: There will be a primary answer is to be placed in the balance with the concept of improvement of local-domestic concept in terms of the distribution of the target group is clear. Conclusion of this understanding is: Papua, a word of plural form in Melanesian-Papua alloys; an universals of salient aspects shown autonomously which are intertwined in the combined of hidden structure forming a synergistic circular mosaic give each other mutual interests in the estuary for the principle of love, loyal, honest and sustainable in the spirit of one nation, one soul and one solidarity. Furthermore, how Papua to Indonesia is extra work for all the parties to give balance matching cohesive space being productive and beneficial to both parties Indonesia and Papua. Accordingly, we are required to understand the concept of culture in Melanesian-Papua is no strong interrelationship although not apparent due to appear mosaic but summarized in reasoning and feel (hidden structure). On the other hand the expression "wantok" in Tok Pizin is so strong binding the Melanesian communities that exist primarily in the path of political struggle and solidarity rights. In West Papua is a password struggle blaze slogan "One Nation-One Soul-One Solidarity". Over solidarity to the struggle of West Papua- Melanesia, Vanuatu in 2010 published a specific Act on West Papua called "Wantok blong Youme Bill" (Bill to the fellow Melanesia of West Papua). [16] From this exposure, Melanesia had meet three criteria of philosophy as human, thinker and as well as social beings who express emotions, provide a way out and bring together a balanced including to the other linkage.[17]

Very urgent in 2015 since June to September and then, the growing regionalism concern over the plight of Papuans in West Papua has been demonstrated in such key regional groupings as the Melanesian Spearhead Group (MSG) and the Pacific Islands Forum. Now, regionalism leaders have brought their concerns to the United Nations General Assembly (UNGA). Their remarks sparked what may be the first discussion in the UNGA on West Papua since the UN body "took note" of the Act of Free Choice in 1969 by concern over human rights and "called all parties to protect and uphold the human rights of all residents in Papua (http://etan.org/issues/wpapua/2015/1510wpap.htm). NOT ROOT OF THE PROBLEM rather ROOT OF THE CAUSE.

\section{Conclusion}

This closure may be given in the following conclusion: The studies of Melanesia focused Anthropology called Melanesianology and The studies of Papua focused on Linguistics called Papuanistiec. Characteristic expression of different cultures in Papua-Melanesian by people outside the system looks expressed as loosely structured (unstructured) or confusion diversity that is for those inside the system actually is hidden (hidden) because it does not seem to surface while the people in the culture of these relations is clear. With the approach of the theory of the structure linkage (structures relationship), historical study (study of history), and also functional study (study of functions) based British Anthropology the relations which said to be non-visible can be seen and explained. Based on the concept of Field of Study/ FoS (zoning Studies) then

16 The wantok Blong Yumi Bill The wantok tension Yumi Bill was the decision unanimously adopted by the Parliament of Vanuatu in June 2010, is derived from the "People's Petition", tabled in the Parliament by Independent MP Ralph Regenvanu. The purpose of the bill was to express Vanuatu recognition of the independence of West Papua from Indonesia and Vanuatu to implement actively seek observer status to West Papua in MSG and FIP. The bill is supported by both the Prime Minister and opposition leader Edward Natapei Maxime Carlot Korman, along with their respective parties. The Government stated that the bill would "allow for developed the specific policies on how to support the struggle for independence of West Papua", fulfilling the dream of Fr Walter Lini first Prime Minister founder of Vanuatu, once said [sic ]: "Vanuatu will not rest until it sees the brothers in Melanesia get their freedom".

${ }^{17}$ Even in the US HR 2410 2009, at paragraphs 1123 specifically about West Papua on the last point (11) said: the Papuans in West Papua are ethnic Melanesians and is believed to be derivative of Africa. 
the color of cultures in Southeast Asia and Oceania (Polynesia, Micronesia and Melanesia) because of the spreading of Malayo-Polynesian languages or now known as Austronesian, then the two regions by understanding of University of Leiden (Leiden structuralism) used as an ethnographic study region: TaalLand-en-Volkenkunde (linguistic, cultural, and tribal). With the culture material protruding from 7 to 9 aspect universal culture, the typical areas called Cultural Division (Regional Cultures) into 7 regions in Tanah Papua (West Courant of Papua), 5 territories do in PNG, Super stock Region of Melanesia Pacific Islands (Fiji, Kanaki, Vanuatu, Solomon, Kiribat) and Emporium Region of Melanesian Islands archipelago (Maluku, Nusa Tenggara and Moro-Southern of the Philippines). The tight among Melanesia and thus Papua is chain of Melanesian Spirit Brotherhood: One People, One Soul and One Solidarity and Papuan Spirit of Luster: Mercy, Honest and Justice. This is where Papua case had to be taken in seriouse concern (e.g. Vanuatu of Wantok blong Youme Bill). Melanesianology and Papuanistiec are very well coordinated by Sydney University and the Australian National University in Canberra by integrating moving of the University of Papua New Guinea/UPNG in Port Moresby PNG and University of South Pacific/USP in Suva-Fiji.

Implimentations: If the Cendrawasih University has ever launched Based Science on Anthropology, then the function of Melanesianology and Papuanistiec can make as major studies take precedence in all disciplines.

\section{References}

Baal, J. V. (1966). DEMA Description and Analysis of Marind Anim Culture (South New Guinea), with the collaboration of Father J. Verschuren, MSC, The Hague, Nartinus Nijhof.

Barnes, J. A. (1948). African models in the New Guinea Higlands, in Man 2

Boas, F. (1911). Handbook of Amerixan Indian Languages",1,2 in Bulletin of the Bureau of American Ethnology, 401938 Handbook of American Indian Languages, 3, New York : Angustin.

Cassirer, E. (1953-1957). Philosophy of Symbolic Forms (1923-29), English translation

Elmberg J. E. (1966b). The Popot Feast Cyle in Ethnos, Stockholm:Statens Etnografiska, Musset. 1968 Balance and Circulation: Tradition and Change Among the Maybart of Irian Barat, Stokholm : Etnografisika Musset Monograph Series No.12

Flassy, D. A. L. (1983). Aspek dan Prospek Seni Budaya Irian Jaya, Jayapura, Pemda Tk.I Irian Jaya.

Gerbrand, A. (1970). Language of Things: Studies in Ethno-communication In Honour of Professor Adrian A. Gerbrands, edited by Keurs and Smidt, (1975).

Held, G. J. (1951). De Papoea cultuurim-provisator,'s Gravenhage/Bandung : van Hoeve.

Feil, K. (1979). The Evolution of Highland Papua New Guinea Societie, Cambridge: Uni. Press.

Leeden, A. (1956). Hoofdtrekken der sosiale struktuur in het westelijke binnenland van Sarmi thesis Rijksuniversiteit te Leiden. Malinowski Borislav. 1922 Argonauts of the Western Pacific dalam Review Melissa Hannequin, Fairfield University, Connecticut, USA 3 October 2012

Mansoben, J. R. (1994). Sistem politik tradisional di Irian Jaya, Indonesia, Studi Perbandingan, Leiden: PhD. thesis, University of Leiden.

Mansoben, J. R. (2009). Proceedings of International Conference on Papuan Culture Diversity in The Mosaic of Indonesian Culture, Jayapura, LRP. Masinabow, 1983, Halmahera dan Raja Ampat Sebagai Kesatuan Majemuk: Studi-studi terhadap suatu daerah transisi, i - vi. Jakarta, Leknas-LIPI. Mead Margareth, 1930 Growing Up in New Guinea: A Comparative Study of Primitive Education on Amazon.com. Meteray Bernada, 2012 Nasionalisme Ganda Orang Papua, Jakarta, Kompas.

Narakobi, B. (1980). The Melanesian Way, Institute of Papua New Guinea Studies.

Narakobi, B. (1984). The Old and the New, in Gernot Fugmann ed.

Pike, K. L. (1967). Language in relation to a unified theory the struktur of human behavior, The Hague - Paris: Mouton

Pouwer, J. (1966). Types of kinship and descent Kinship and descent in Mimika and Asmat, Wikepwedia.

Pullan, W. (2000). Struktur. Cambridge: Cambridge University Press.

RI-Law No, 21. (2001) Special Autonomy for the Province of Papua/OTSUS.

Rowe, J. C. (1995). Struktur, in Critical Terms for Literary Study, 2nd ed., ed. Frank Lentricchia and Thomas McLaughlin, (Chicago and London: University of Chicago Press.

Secretariat of Melanesian Spear Head Group, Leaders Summit, June 2015, The Communique of MSG.

Secretariat of Pacific Island Forum, Leader Summit, Sept 2015, The Communique of The PIF.

Stokhof, W. A. L. (1988). IRIS-ISIR Project, Leiden. 


\section{Journal of Education and Vocational Research (ISSN 2221-2590)}

Vol. 8, No. 1, pp. 37-47, March 2017

Sydney University and RSPAS ANU-Canberra, 2006-2008 27-29 Papuanistiec an Melanesianology (Consept of October 2006 - 28-29 June 2008).

UN. (1945). Charter.

UN. (1948). General Declaration of Universal Human Right.

UN. United Nations General Assembly resolution 1514 (XV) on The United Nations and Decolonization Declaration.

US HR 2410. (2009). at paragraphs 1123 (Bill on West Papua).

Vanatu. (2010). Wantok Blong Yu Me Bill (Bill on West Papua)

www.academia. 